\title{
THE EFFECT OF COMPENSATION TO EMPLOYEE PERFORMANCE WITH WORK SATISFACTION AS INTERVENING VARIABLES IN THE FINANCIAL OFFICE OF WEST SUMATERA PROVINCE
}

\author{
Dona Yendra, Aminar Sutra Dewi \\ Sekolah Tinggi Ilmu Ekonomi KBP \\ donayendra007@gmail.com
}

\begin{abstract}
The performance of the employee produces the quantity and quality that the employee gains on the actual behavior shown in accordance with the responsibilities given to him. This study aims to examine the effect of compensation on employee performance with job satisfaction as intervening variable. Problems that occurred at the Office of Regional Finance Agency of West Sumatra Province is the issue of leadership to employees who neglect in work, in the employee's work is not timely completion of tasks given by the leadership example in the manufacture of letters not on time and delay in work. Population in this research is civil servant at Regional Finance Board of West Sumatera Province. The sample in this study amounted to 30 respondents, the study was selected by using purposive sampling technique. The data were collected from respondents and analyzed by simple linear regression, $t$ test, test of test, and path analysis test. The result of the research shows that compensation has an effect on employee performance positively and significantly. Compensation affects job satisfaction positively and significantly, job satisfaction on employee performance and job satisfaction have positive and significant effect directly to employee's compensation and performance. This means that high job satisfaction in accordance with compensation will bring high performance employees at the Regional Finance Agency of West Sumatra Province.
\end{abstract}

Keywords: Compensation, Job Satisfaction and Employee Performance

\section{PENDAHULUAN}

Kinerja pegawai merupakan hasil kerja yang sesuai baik kualitas atau kuantitas yang menghasilkan kinerja pegawai dengan perilaku nyata yang ditampilkan sesuai dengan kerja yang mereka berikan. Kinerja juga hasil kerja merupakan hasil yang akan disumbangkan oleh pegawai yang berkaitan dengan tugas atau tanggung jawab kepada perusahaan. Oleh karena itu kinerja pegawai yang cukup bagus perusahaan pengharapkan perusahaan mampu bersaing dengan yang lain sehingga dapat diakui bahwa perusahaan mempunyai kinerja cukup berkualitas. Permasalahan yang terjadi pada Kantor Badan Keuangan Daerah Provinsi Sumatera Barat yaitu masalah pimpinan kepada pegawainya yang lalai dalam bekerja, dalam bekerja pegawai tersebut tidak tepat waktu menyelesaikan tugas yang dikasiholeh pimpinan contohnya dalam pembuatan 
surat-surat tidak on time dan keterlambatan dalam bekerja.

Kinerja pegawai menghasilkan kuantitas maupun kualitas yang diperoleh pegawai terhadap perilaku nyata diperlihatkan sesuai tanggung jawab yang diberikan kepadanya. Penelitian oleh (Murty \& Hudiwinarsih, 2012) dengan penelitian Pengaruh Kompensasi, Motivasi Dan Komitmen Organisasional Terhadap Kinerja Karyawan Bagian Akuntansi (Studi Kasus Pada Perusahaan Manufaktur Di Surabaya. Hal ini menunjukan bahwa kompensasi berpengaruh positif dan signifikan terhadap kinerja karyawan.Penelitian oleh (Fathonah \& Utami, 2011) dengan peneltian Pengaruh Kompensasi, Pengembangan Karir, Lingkungan Kerja Dan Komitmen Organisasi Terhadap Kepuasan Kerja Pegawai Sekretariat Daerah Kabupaten Karanganyar Dengan Keyakinan Diri (Self Efficacy) Sebagai Variabel Pemoderasi.

Kompensasi merupakan hal yang cukup penting karena kompensasi dapat menarik perhatian, menjaga dan memelihara pegawai supaya tidak meninggalkan perusahaan. Kompensasi yaitu segala yang diterima oleh pegawai untuk balas jasa dalam kerja mereka.Kendala kompensasi merupakan fungsi manajemenyang cukup sulit dan membingungkan. Tidak hanyadalam pemberian kompensasi tetapi juga merupakan salah satu hal yang paling berarti, akan tetapi kompensasi juga paling penting bagi karyawan dan juga organisasi. Oleh karena itu, sistem kompensasi hendaknya menguntungkan bagi keuntungan karyawan, memastikan perilaku adil terhadap pegawai untuk memberikan imbalan terhadap kinerja mereka.

Tunjangan yang diberikan oleh perusahaan sangat menarik perhatian bagi para pegawai dan memberikan penjelasan yang jelas dalam mengingatkan penting adanya tunjangan yang akan diberi kepada pegawai, kompensasi juga meningkatkan kinerja pegawai dalam ukuran kerjanya, sehingga membantu pegawai dalam mengalokasikan waktu dan usaha pegawai. Kompensasi juga mempunyai peran yang sangat penting terhadap kinerja pegawai untuk mendapatkan apa yang menjadi pegawai. Kompensasi pada Kantor Badan Keuangan Daerah setiap pegawai memberikan kemampuan yang terbaik dalam menjalankan tugasnya akan diberikan penghargaan oleh atasannya. Oleh karena itu berarti kompensasi yang adil akan meningkat kinerja pegawai.

Kepuasan kerja pegawai yaitu suatu kejadian yang perlu dilihat oleh pimpinan perusahaan. Kepuasan kerja sangat berperan penting terhadap kinerja pegawai. orang yang puas terhadap kinerja akan menjadikan pangaruh penting terhadap pekerjaan yang tinggi, padaakhirnya pegawai terus memperbaiki kinerja mereka. Kepuasaan kerja sangat mempengaruhi kebutuhan dan keinginan dalam kegiatan seseorang saat bekerja.

Selain itu kepuasan kerja juga dapat diartikan sebagai penilaian, perasaan atau sikap seseorang atau pegawai terhadap pekerjaannya dan berhubungan dengan lingkungan kerja, jenis pekerjaan, kompensasi dan ditempat kerja. Untuk itu perusahaan harus melihat dan mengevaluasi agar terus bekerja secara nyaman dengan perasaan senang dan puas karena pegawai yang seperti itu akan memberikan sesuatu yang lebih dari tanggung jawabnya serta akan melakukan perilaku diluar tugas kesehariannya.

Permasalahan yang terjadi pada Kantor Badan Keuangan Daerah Provinsi Sumatera Barat yaitu masalah pimpinan kepada pegawainya yang lalai dalam bekerja, dalam bekerja pegawai tersebut tidak tepat waktu menyelesaikan tugas 
yang dikasiholeh pimpinan contohnya dalam pembuatan surat-surat tidak on time dan keterlambatan dalam bekerja.

Hasil dari penelitian tersebut menunjukan bahwa kompensasi berpengaruh positif dan signifikan terhadap kepuasan kerja. Penelitian oleh (Indrawati, 2013) dengan penelitian pengaruh Kepuasan Kerja terhadap Kinerja Karyawan dan Kepuasan Pelanggan pada Rumah Sakit Swasta di Kota Denpasar. Hasil dari penelitian tersebut menunjukan bahwa kepuasan kerja berpengaruh signifikan dan positif terhadap kinerja karyawan. Kinerja merupakan pencapaian dan tingkatan seseorang dalam mencapai suatu tujuan untuk keberhasilan didalam perusahaan. Kinerja tersebut tidak berdiri sendiri tapi berhubungan dengan kepuasan kerja dan kompensasi, dipengaruhi oleh penampilan, kemampuan, keinginan dan lingkungan (Pottale, 2016).

Kinerja Pegawai adalah hasil kerja yang dapat dicapai oleh seseorang atau sekelompok orang dalam suatu organisas, sesuai dengan wewenang dan tanggung jawab masing-masing dalam rangka mencapai tujuan organisasi yang bersangkutan secar legal, tidak melanggar hukum, dan sesuai dengan moral maupun etika (Rahmawati, 2009).

Kompensasi adalah segala sesuatu yang diterima para pegawai sebagai balas jasa untuk kerja mereka.Masalah kompensasi merupakan fungsi manajemen personalia yang paling sulit dan membingungkan. Penelitian oleh (Nurcahyani, 2016) dengan penelitian pengaruh kompensasi terhadap kinerja karyawan PT.Slamet langgeng purbalingga dengan motivasi kerja sebagai variabel intervening. Penelitian ini menemukan hasil bahwa kompensasi berpengaruh positif dan signifikan terhadap kinerja, sehingga adanya peningkatan pemberian kompensasi akan meningkat kinerja karyawan. Penelitian oleh (Agus et al., 2016) dengan penelitian Pengaruh Kompensasi Dan Disiplin Kerja Terhadap Kinerja Karyawan Pada Hotel Puri Bagus Lovina.Hal ini menunjukan bahwa kompensasi berpengaruh secara positif terhadap kinerja karyawan. Penelitian oleh (Murty \& Hudiwinarsih, 2012) dengan penelitian Pengaruh Kompensasi, Motivasi Dan Komitmen Organisasional Terhadap Kinerja Karyawan Bagian Akuntansi (Studi Kasus Pada Perusahaan Manufaktur Di Surabaya. Hal ini menunjukan bahwa kompensasi berpengaruh positif dan signifikan terhadap kinerja karyawan. Maka hipotesis Diduga Kompensasi berpengaruh positif dan signifikan terhadap Kinerja pegawai.

Kompensasi adalah dasar diperlukan untuk mempertahankan karyawan dengan standar hidup yang layak, akan tetapi kompensasi juga menyediakan suatu pengukuran berwujud mengenai nilai individu bagi perusahaan. Pemberian kompensasi merupakan fungsi strategik sumber daya manusia yang mempunyai imbas singnifikan atas fungsi-fungsi sumber daya manusia lainnya (Murty \& Hudiwinarsih, 2012). Kepuasan Kerja adalah Kepuasan refleksi dari perasaan dan sikap individu terhadap pekerjaannya, yang merupakan interaksi antara yang bersangkutan dengan lingkungan kerjanya.Kesempatan mendapatkan promosi jabatan memiliki efek terhadap kepuasan kerja.

Hal demikian dikarenakan promosi menggunakan beraneka ragam cara dan memiliki penghargaan yang beragam, misalnya promosi berdasarkan tingkat senioritas, dedikasi, pertimbangan kerja. Penelitian oleh (Fathonah \& Utami, 2011) dengan peneltian Pengaruh Kompensasi, Pengembangan Karir, Lingkungan Kerja Dan Komitmen Organisasi Terhadap Kepuasan Kerja Pegawai Sekretariat 
Daerah Kabupaten Karanganyar Dengan Keyakinan Diri (Self Efficacy) Sebagai Variabel Pemoderasi. Hasil dari penelitian tersebut menunjukan bahwa kompensasi berpengaruh positif dan signifikan terhadap kepuasan kerja.

Penelitian oleh (Hestin Mutmainah, 2013). Pengaruh Kompensasi, Pelatihan, Dan Peran Supervisor Terhadap Kinerja Yang Dimediasi Oleh Kepuasan Kerja Pada Karyawan Paguyuban Batik Laweyan Surakarta. Hasil dari penelitian tersebut menunjukan bahwa kompensasi berpengaruh positif dan signifikan terhadap kepuasan kerja. Penelitian oleh (Mekel, 2015). Pengaruh Lingkungan Kerja, Kepuasan Kerja Dan Kompensasi Terhadap Kinerja Karyawan Pada PT. Bank Sulut Cabang Airmadidi. Hasil penelitian tersebut menunjukan bahwa kompensasi berpengaruh positif dan signifikan terhadap kepuasan kerja.maka hipotesis Diduga Kompensasi berpengaruh positif dan signifikan terhadap Kepuasan Kerja.

Kepuasan Kerja yaitu sikap yang emosional menyenangkan atau mencintai pekerjaan.Sikap itulah mencerminkan sikap moral kerja, kedisiplinan dan prestasi kerja.Kepuasan kerja dinikmati dalam perkerjaan ataupun diluar pekerjaan. Sehinggapegawai akan berusaha dan bahkan meningkatkan kinerjanya dalam peusahaan. Kinerja pegawai merupakan hasil yang cukup baik dalam mencapai kualitas ataupun kuantitas yang menghasilkan pegawaidan perilaku yang nyata ditampilkan sesuai dengan tanggung jawabyang diberikan kepadanya.Kinerja juga merupakan hasil kerja yang dihasilkan atau disumbangkan seorang karyawan yang berkaitan dengan tugas dan tanggungjawab kepada perusahaan.

Penelitian oleh (Indrawati, 2013) dengan penelitian pengaruh Kepuasan Kerja terhadap Kinerja Karyawan dan Kepuasan Pelanggan pada Rumah Sakit Swasta di Kota Denpasar. Hasil dari penelitian tersebut menunjukan bahwa kepuasan kerja berpengaruh signifikan dan positif terhadap kinerja karyawan. Penelitian oleh (Ketut \& Juli, n.d.) dengan penelitian Pengaruh Kompensasi dan Motivasi Terhadap Kepuasan dan Kinerja Karyawan pada Hotel Bakung's Beach Cottages Kuta-Bali.

Hasil dari penelitian tersebut menunjukan bahwa kepuasan kerja berpengaruh positif dan signifikan terhadap kinerja pegawai. Penlitian oleh (Murti \& Srimulyani, 2013) dengan penelitian Pengaruh Motivasi Terhadap Kinerja Pegawai Dengan Variabel Pemediasi Kepuasaan Kerja Pada Pdam Kota Madiun. Hasil dari penelitian tersebut bahwa kepuasan kerja berpengaruh positif dan signifikan terhadap kinerja. Maka hipotesis Diduga Kepuasan Kerja berpengaruh positif dan signifikan terhadap Kinerja pegawai.

Penelitian (Nurcahyani, 2016) menyatakan bahwa tidak ada suatu organisasi yang dapat memberi kekuatan baru yang dapat meningkatkan produktivitas karyawannya jika badan usaha tersebut tidak memiliki sistem kompensasi yang realistis. Uang bukan satu-satunya motivasi individu bekerja, tetapi tidak boleh lupa karyawan harus diberi penghargaan berupa kompensasi finansial untuk mencapai kinerja yang produktif. Diduga system kompensasi dapat menjadi awal dan akhir dari kepuasan kerja seorang karyawan. Oleh karena itu, jika sistem kompensasi baik dan meningkat, maka akan menimbulkan persaan senang atau puas terhadap pekerjaan. Kondisi tersebut dapat dapat menjadi faktor yang mendorong seorang karyawan untuk menunjukkan kinerja individu yang tinggi sesuai harapan perusahaan. Penelitian Pengaruh Kompensasi Dan Motivasi Terhadap Kinerja Karyawan Dengan Kepuasan Kerja Sebagai Variabel 
Intervening.

Hasil dari penelitian ini menunjukkan bahwa kompensasi positif berpengaruh signifikan terhadap kinerja karyawan,pengaruh motivasi terhadap kinerja karyawan menunjukkan bahwa motivasi secara positif berpengaruh signifikan terhadap kinerja karyawan, Pengujian pada pengaruh kepuasan kerja terhadap kinerja karyawanmenunjukkan bahwa kepuasan kerja secara positif berpengaruh signifikan terhadap kinerja karyawan. Persamaan pada penelitian ini yaitu sama-sama meneliti mengenai pengaruh kompensasi terhadap kepuasan kerja sebagai variabel intervening. Maka hipotesis Diduga Kompensasi berpengaruh terhadap kinerja pegawai dengan kepuasan kerja sebagai variabel intervening.

\section{METODE PENELITIAN}

Penelitian ini termasuk pada penelitian kuantitatif yang mana ada angkaangka yang terdapat pada penelitian ini. penelitian kuantitatif menggunakan skala numeric, berbasis pola alur deduktif, dimana untuk menjawab rumusan masalah digunakan teori atau konsep untuk dapat merumuskan hipotesis.Populasi merupakan suatu wilayah generalisasi yang terdiri dari objek yang mempunyai kuantitas dan karakteristik tertentu yang ditetapkan oleh peneliti untuk di pelajari dan kemudian ditarik kesimpulannya.Oleh karena itu dapat disimpulkan bahwa populasi dapat berupa subyek (orang) ataupun objek (tempat) yang karakteristik berbeda dan bisa diteliti. Dalam penelitian ini peneliti mengambil populasi pada 30 pegawai PNS Badan Keuangan Daerah Provinsi Sumatera Barat, Populasiyang ada akan diambil sejumlah tertentusebagaisampel..Pengambilan sampel penelitian dilakukan dengan metodepurposive sampling.Sedangkan untuk teknik pengumpulan data didapat melalui Survei, Observasi, Interview, dan Dokumentasi yang mana data bisa di dapat langsung pada pegawai Dadan Keuangan Daerah Provinsi Suamatera Barat yang telah memplubikasikan ringkasan berdasarkan objek yang dibutuhkan.

\begin{tabular}{|c|c|c|c|}
\hline Variabel & Definisi & Indikator & Skala \\
\hline Kinerja (Y) & $\begin{array}{l}\text { Kinerja menurut Rivai (2005) yaitu : } \\
\text { Hasil atau tingkatan keberhasilan } \\
\text { seseorang secara keseluruhan selam } \\
\text { peroide tertentu. }\end{array}$ & $\begin{array}{l}\text { 1. Prestasi kerja } \\
\text { 2. Pencapaian } \\
\text { target } \\
\text { 3. Keterampilan } \\
\text { 4. Kepuasan } \\
\text { 5. Inisiatif } \\
\text { (Robbin, 2005) }\end{array}$ & Skala Likert \\
\hline $\begin{array}{l}\text { Kompensasi } \\
\text { (X) }\end{array}$ & $\begin{array}{l}\text { Kompensasi menurutRivai (2004) } \\
\text { kompensasi merupakan sesuatu yang } \\
\text { diterima pegawai sebagai pengganti } \\
\text { distribusi jasa mereka pada perushaan. }\end{array}$ & $\begin{array}{l}\text { 1. Upah gaji } \\
\text { 2. Insentif } \\
\text { 3. Tunjangan } \\
\text { 4. Fasilitas } \\
\text { (Henry } \\
\text { Simmamora, 2004) }\end{array}$ & Skala Likert \\
\hline $\begin{array}{l}\text { Kepuasan } \\
\text { Kerja (Z) }\end{array}$ & $\begin{array}{l}\text { Kepuasan Kerja menurut } \\
\text { Robbins(2003) adalah kepuasan kerja } \\
\text { merujuk kepada sikap umum seorang } \\
\text { individu terhadap pekerjaan yang } \\
\text { dilakukannya. }\end{array}$ & $\begin{array}{l}\text { 1. Pekerjaan } \\
\text { 2. Gaji } \\
\text { 3. Promosi } \\
\text { 4. Pengawasan } \\
\text { 5. Rekan kerja } \\
\text { (Yuwono, 2015) }\end{array}$ & Skala Likert \\
\hline
\end{tabular}




\section{Teknik Analisis Data}

Teknik analisis data yang digunakan dalam penelitian ini adalah metode analisis statistik. Analisis data menggunakan SPSS 16, yang dimana teknik analisis data yang digunakan oleh peneliti adalah:

1. Uji Instrumen Data

a. Uji Validitas yaitu suatu langkah untuk melakukan pengujian terhadap validitas dari suatu content instrumen, dengan tujuan untuk mengukur ketepatan yang digunakan oleh penelitian, Uji validitas ini dikatakan valid apabila semua indikator-indikator yang digunakan diatas angka 0,30 .

b. Uji Reliabilitas Uji reliabilitas merupakan suatu ukuran kestabilan ataupun konsistensi dalam menjawab responden hal itu berkaitan dengan konstruk-konstruk pertanyaan yang merupakan kriteria dalam variabel maka disusun dalam bentuk kuisioner. Jika $r$ Alpha positif, serta $r>0,70$ maka dimensi tersebut reliabel. Jika r Alpha negatif, serta $\mathrm{r}<0,70$ maka dimensi tersebut tidak reliabel.

2. Statistik Deskriptif Analisis

Statistik deskriptif adalah penyajian data secara numerik.Statistik deskriptif menyajikan ukuran-ukuran numerik yang sangat penting bagi data sampel.Statistik deskriptif juga digunakan untuk mengetahui nilai rata-rata, minimal, maksimal dan standar deviasi dari variabel-variabel yang diteliti.

3. Uji Asumsi Klasik

Uji asumsi klasik digunakan untuk menguji apakah model regresi benar-benar menunjukkan hubungan yang signifikan dan representatif. Ada tiga pengujian dalam uji asumsi klasik, yaitu:

a. Uji normalitas data Pengujian normalitas dilakukan untuk mengetahui sebuah data berdistribusi normal atau tidak. Jika nilai probabilitas > 0,05 maka Ho diterima,Jika nilai probabilitas < 0,05 maka Ho ditolak

b. Uji Heteroskedastisitas untuk menguji apa benar dalam model regresi terjadi ketidaksama anvariance dari residual satu pengamatan kepengamatan yang lain. Jika variance residual hanya satu pengamatan tetap, dapat disimpulkan homoskedastisitas berbeda yaitu heteroskedastisitas Jika pvalue > 0,05 tidak signifikan berarti tidak terjadi heteroskedastisitas artinya model regresi lolos uji heteroskedastisitas

4. Analisis Regresi Linear Sederhana

Analisis regresi sederhana didasarkan pada hubungan fungsional ataupun satu variabel independen dengan satu variabel dependen (Sugiyono, 2015).

Persamaan umum regresi linier sederhana adalah:

a. Pengaruh Kompensasi terhadap Kinerja Karyawan

$\mathrm{Y}=\mathrm{a}+\mathrm{bX}+\mathrm{e}$

Dimana:

$\mathrm{Y}=$ kinerja Karyawan

$\mathrm{a}=$ Konstanta

$\mathrm{b}=$ Koefisien regresi

$\mathrm{X}=$ Kompensasi 
$\mathrm{e}=$ error

b. Pengaruh Kompensasi terhadap Kinerja Karyawan

$\mathrm{Z}=\alpha+\mathrm{bX}+\mathrm{e}$

Dimana :

$\mathrm{Z}=$ Kepuasan Kerja

$\alpha=$ Konstanta

$\mathrm{b}=$ Koefisien regresi

$\mathrm{X}=$ Kompensasi

$\mathrm{e}=$ error

c. Pengaruh Kompensasi terhadap Kinerja Karyawan

$\mathrm{Y}=\alpha+\mathrm{bZ}+\mathrm{e}$

Dimana :

$\mathrm{Y}=$ Kinerja Pegawai

$\alpha=$ Konstanta

$\mathrm{b}=$ Koefisien regresi

$\mathrm{Z}=$ Kepuasan Kerja

$\mathrm{e}=$ error

5. Analisis Jalur (Path Analysis)

Perbedaan analisis ini dengan regresi adalah jika pada umumnya regresi digunakan untuk menguji apakah ada pengaruh langsung yang diberikan variabel bebas kepada variabel terikat.Namun pada analisis jalur tidak hanya menguji pengaruh lagsung saja tetapi juga menjelaskan tentang ada atau tidaknya pengaruh tidak langsung yang diberikan oleh variabel bebas melalui variabel intervening terhadap variabel terikat. Adapun model regresi yang digunakan dalam analisis jalur ini adalah :

$\mathrm{Y}=\alpha+\mathrm{bI}+\mathrm{e}$

Dimana:

$\mathrm{Y}=$ kinerja Karyawan

$\mathrm{a}=$ Konstanta

$\mathrm{b}=$ Koefisien regresi

$\mathrm{I}=$ Intervening

$\mathrm{e}=$ error

6. Uji Hipotesis

Uji ini digunakan untuk mengetahui pengaruh bersama-sama variabel bebas terhadap varibel terikat (Pottale, 2016).

a. Uji Parsial (Uji T) pengujian koefisien regresi masing-masing variabel independen terhadap dependen untuk melihat seberapa besar pengaruh dari variabel independen terhadap variabel dependen.

b. Uji Sobel Test Uji Sobel dilakukan dengan cara menguji kekuatan pengaruh tidak langsung variabel Independen ke variabel dependen melalui variabel mediasi.

\section{HASIL DAN PEMBAHASAN}

Analisis RegresiLinear Sederhana

Analisis regresi sederhana hubungan secara linear antara satu variabel bebas dengan variabel terikat untuk mengetahui arah hubungan antar variabel.Hasil analisis regresi linear sederhana yang diolah dengan menggunakan program SPSS, diringkas pada Tabel 1. 
Tabel 1

Hasil Analisa Regresi Linear Sederhana

Coefficients $^{\mathrm{a}}$

\begin{tabular}{|c|c|c|c|c|c|}
\hline \multirow[b]{2}{*}{ Model } & \multicolumn{2}{|c|}{ Unstandardized Coefficients } & \multirow{2}{*}{$\begin{array}{c}\text { Standardized } \\
\text { Coefficients } \\
\text { Beta }\end{array}$} & \multirow[b]{2}{*}{$\mathrm{T}$} & \multirow[b]{2}{*}{ Sig. } \\
\hline & B & Std. Error & & & \\
\hline $1 \quad$ (Constant) & 62.441 & 10.325 & & 6.047 & .000 \\
\hline KO : Kompensasi & .345 & .213 & .293 & 1.622 & .116 \\
\hline
\end{tabular}

a. Dependent Variable: KP : Kinerja Pegawai

Sumber: Data SPSS, Lampiran 6

Dari hasil analisis data yang disajikan pada Tabel 1 dapat diinterpretasikan sebagai berikut :

$$
\mathrm{Y}=62,441+0,293 \mathrm{X}+\mathrm{e}
$$

Dari persamaan tersebut dapat diartikan bahwa bahwa kompensasi memiliki nilai koefisien regresi sebesar 0,345. Hal ini menunjukan bahwa jika terjadi kenaikan tindakan kompensasi sebesar 1 maka nilai dari kinerja pegawai sebesar 62,411 dengan asumsi bahwa variabel lainnya konstan.

\section{Analisis Jalur (Path Analysis)}

Metode analisis jalur (Path Analysis) digunakan untuk menguji pengaruh variabel intervening (Mediasi).

\section{Tahap Menghitung Koefisien Jalur}

\section{Koefisien Jalur}

Untuk hasil koefisien jalur pada model mediasi ini dapat dapat dilihat dari tabel hasil olahan model regresi yang kesatu dibawah ini :

Tabel 2

\begin{tabular}{|ll|r|r|r|r|r|}
\hline \multirow{2}{*}{ Model } & \multicolumn{2}{|c|}{$\begin{array}{c}\text { Unstandardized } \\
\text { Coefficients }\end{array}$} & $\begin{array}{c}\text { Standardized } \\
\text { Coefficients }\end{array}$ & & \\
\cline { 3 - 5 } & \multicolumn{1}{c|}{$\mathrm{B}$} & Std. Error & \multicolumn{1}{c|}{ Beta } & \multicolumn{1}{c|}{$\mathrm{T}$} & \multicolumn{1}{c|}{ Sig. } \\
\hline 1 & (Constant) & 52.101 & 11.923 & & 4.370 & .000 \\
& $\mathrm{KO}:$ Kompensasi & .034 & .283 & .029 & .120 & .905 \\
& $\mathrm{KK}$ & .447 & .278 & .387 & 1.609 & .119 \\
\hline
\end{tabular}

Sumber : Lampiran 7

Dari hasil regresi model mediasi pada tabel coefficient dapat diketahui bahwa nilai signifikan dari kesatu variabel yaitu $X=0,905$ dan $Z=0,119$ lebih besar dari 0,05 . Hasil ini memberikan memberikan kesimpulan bahwa regresi model kedua, yakni variabel $\mathrm{X}$ dan $\mathrm{Z}$ berpengaruh tidak signifikan terhadap $\mathrm{Y}$. Nilai $\mathrm{R}^{2}$ pada model ini sebesar 0,166 . Hal ini menunjukan bahwa kontribusi atau sumbangan pengaruh $\mathrm{X}$ dan $\mathrm{Z}$ terhadap $\mathrm{Y}$ adalah sebesar 16,6\% sedangkan sisanya sebesar $83,4 \%$ merupakn kontribusi dari variabel-variabel lain yang tidak dimasukan dalam penelitian.

Sementara itu, untuk nilai e1 dapat dicari dengan rumus :

$$
=\sqrt{1-0,166}=\sqrt{0,834}=0,91
$$

Dengan demikian diperoleh diagram jalur model struktur kedua sebagai berikut : 


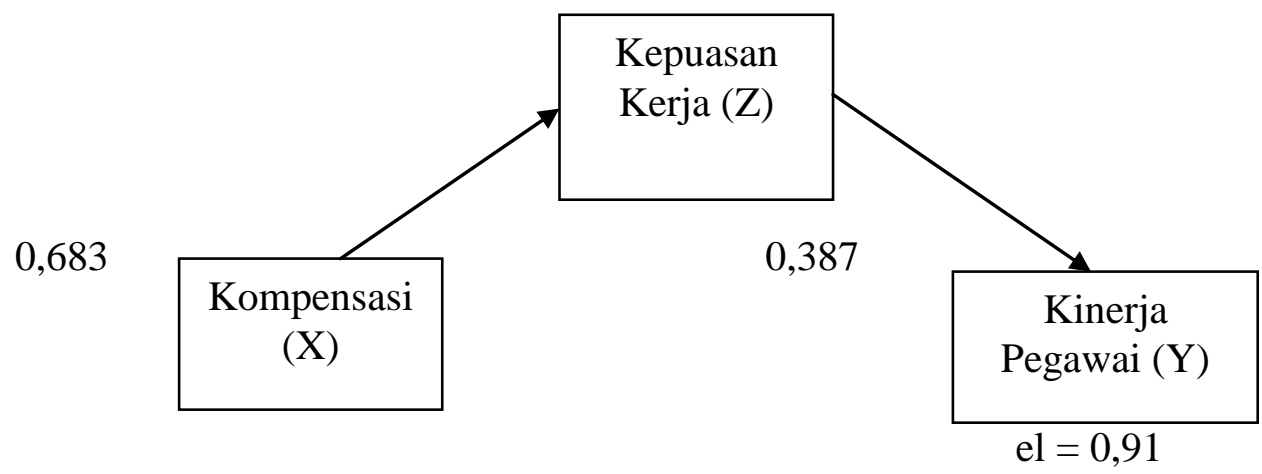

Dapat disimpulkan Analisis Pengaruh X melalui Z terhadap Y diketahui pengaruh langsung diberikan $X$ terhadap $Z$ sebesar 0,029. Sedangkan pengaruh tidak langsng $\mathrm{X}$ melalui $\mathrm{Y}$ terhadap $\mathrm{Z}$ adalah berkaitan antara nilai beta $\mathrm{X}$ terhadap $\mathrm{Y}$ dengan nilai beta $\mathrm{Y}$ terhadap $\mathrm{Z}$ yaitu $=0,034 \times 0,447=0,015198$. Maka pengaruh total yang diberikan $\mathrm{X}$ terhadap $\mathrm{Z}$ adalah pengaruh langsung ditambah dengan pengaruh tidak langsung yaitu : $0,034+0,447=0,481$. Berdasarkan hasil perhitungan diatas diketahui bahwa nilai pengaruh langsng sebesar 0,683 dan pengaruh tidak langsung sebesar 0,387 yang berarti bahwa nilai penagruh tidak langsung lebih sebesar dibandingkan dengan nilai pengaruh langsung, hasil ini menunjukan bahwa secara tidak langsung $X$ melalui $\mathrm{Z}$ mempunyai pengaruh signifikan terhadap $\mathrm{Y}$.

\section{Uji Hipotesis}

\section{Uji Parsial (Uji T)}

Berdasarkan hasil pengujian data yang telah dilakukan diperoleh ringkasan hasil terlihat pada tabel 2 dibawah ini:

Tabel 2

Hasil Uji Parsial (Uji T)

\begin{tabular}{|ll|r|r|r|r|r|}
\hline & & \multicolumn{2}{|c|}{$\begin{array}{c}\text { Unstandardized } \\
\text { Coefficients }\end{array}$} & $\begin{array}{c}\text { Standardized } \\
\text { Coefficients }\end{array}$ & & \\
\cline { 3 - 5 } Model & \multicolumn{1}{c|}{$\mathrm{B}$} & Std. Error & \multicolumn{1}{c|}{ Beta } & \multicolumn{1}{c|}{ T } & \multicolumn{1}{c|}{ Sig. } \\
\hline 1 & (Constant) & 52.101 & 11.923 & & 4.370 & .000 \\
& KO : Kompensasi & .034 & .283 & .029 & .120 & .905 \\
& KK & .447 & .278 & .387 & 1.609 & .119 \\
\hline
\end{tabular}

Adapun hasil dari pengujian statistik t (uji t) pada penilitian ini adalah sebagai berikut :

Berdasarkan hasil pengujian uji $\mathrm{T}$ diatas dapat disiumpulkan bahwa nilai bahwa nilai $\mathrm{T}$ hitung Kompensasi terhadap kinerja pegawai sebesar 0,120 dan T tabel 2,048 dengan signifikan 0,905 > 0,05. Hal ini berarti T hitung lebih kecil dari $\mathrm{T}$ tabel dan signifikan $>0,05$ diterima dan Ho ditolak, artinya kompensasi berpengruh terhadap kinerja pegawai.

Berdasarkan hasil pengujian uji $\mathrm{T}$ diatas dapat disimpulkan bahwa nilai T hitung Kepuasan Kerja terhadap Kinerja Pegawai sebesar 1,609 dan T tabel 2,048 dengan signifikan 0,119>0,05. Hal ini berarti $\mathrm{T}$ hitung lebih kecil dari $\mathrm{T}$ tabel dan signifikan > 0,05 diterima dan Ho ditolak, artinya Kepuasan Kerja berpengruh terhadap kinerja pegawai.

\section{Uji Sobel Test}

Uji Sobel digunakan dalam melakukan pengujian hipotesis mediasi. Uji Sobel dilakukan dengan cara menguji kekuatan pengaruh tidak langsung 
variabel Independen ke variabel dependen melalui variabel mediasi. Besarnya Standar Error pengaruh tidak langsung ( Indirect Effect) dihitung dengan rumus :

$$
\mathrm{Sab}=\sqrt{b^{2} S a^{2}+a^{2} S b^{2}+S a^{2} S b^{2}}
$$

Dari nilai $S a b(S)$ yang diperoleh, dapat dihitung nilai $t$ statistik pengaruh mediasi. Dan dibandingkan dengan nilai t-tabel untuk melihat pengaruh mediasinya. Nilai t statistik dihitung dengan rumus : $t \frac{a b}{S a b}$

Pengaruh kompensasi terhadap kinerja pegawai dimediasi oleh kepuasan kerja.

$$
\begin{array}{rl}
\mathrm{a}=0,29 & \mathrm{a} 2=0,0841 \\
\mathrm{~b}=0,000 & \mathrm{~b} 2=0 \\
\mathrm{Sa}=0,283 & \mathrm{Sa} 2=0,080089 \\
\mathrm{Sb}=0,278 & \mathrm{Sb} 2=0,077284 \\
\mathrm{~S}= & \\
\sqrt{(0)(0,080089)+(0,0841)(0,077284)+(0,080089)(0,077284)} \\
\mathrm{S}=\sqrt{0+0,006499+0,006189} \\
\mathrm{~S}=\sqrt{0,012688} \\
\mathrm{~S}=0,112641 & \\
\mathrm{t}=\frac{(0,29)(0,000)}{0,112641} & \\
\mathrm{t}=0
\end{array}
$$

Oleh karena itu nilai t-hitung 0 lebih kecil dari t-tabel dengan tingkat signifikan 0,05 yaitu sebesar 2,048, bahwa koefisien mediasi tidak signifikan yang berarti tidak ada pengaruh mediasi. Dengan demikian dapat disimpulkan bahwa kepuasan kerja tidak memediasi secara signifikan pengaruh kompensasi terhadap kinerja pegawai.

\section{Pembahasan}

\section{Pengaruh Kompensasi terhadap Kinerja Pegawai}

Berdasarkan hasil pengujian hipotesis pertama, ditemukan bahwa variabel kompensasi berpengaruh positif dan signifikan terhadap kinerja Pegawai PNS Badan Keuangan Daerah Provinsi Sumatera Barat. Besaran koefisien regresi variabel kompensasi adalah 0,120 dan signifikansinya 0,905 yang lebih kecil dari $\alpha=0,05$.

Hal ini dapat diartikan bahwa variabel Kompensasi berpengaruh positif dan signifikan terhadap kinerja pegawai.Dengan demikian, hipotesis pertama $\left(\mathrm{H}_{1}\right)$ dalam penelitian ini yang menyatakan bahwa Kompensasi berpengaruh positif dan signifikan terhadap kinerja pegawai pegawai PNS Badan Keuagan Daerah Provinsi Sumatera Barat, dinyatakan dapat diterima.

Menurut Rivai (2004) Kompensasi merupakan hal yang sangat penting karena kompensasi yang cukup dapat menarik, memelihara dan menjaga pegawai agar kinerja pegawainya semakin bagus dalam menjalankan segala tugas yang diberikan oleh perusahaan.Penelitian oleh (Agus et al., 2016)dengan penelitian Pengaruh Kompensasi Dan Disiplin Kerja Terhadap Kinerja Karyawan Pada Hotel Puri Bagus Lovina.Hal ini menunjukan bahwa kompensasi berpengaruh secara positif terhadap kinerja karyawan.

Hal ini bermakna bahwa semakin tinggi kompensasi yang dimiliki oleh pegawai PNS Badan Keuangan Daerah Provinsi Sumatera Barat maka kondisi 
tersebut akan dapat mempengaruhi secara positif dan signifikan terhadap kinerja pegawai pada Badan Keuangan Daerah Sumatera Barat.

\section{Pengaruh Kompensasi Terhadap Kepuasan Kepuasan Kerja}

Berdasarkan hasil pengujian hipotesis kedua, ditemukan bahwa variabel kompensasi berpengaruh positif dan signifikan terhadap kepuasan kerja pegawai PNS Badan Keuangan Daerah Provinsi Sumatera Barat.Besaran koefisien regresi variabel kompensasi adalah 0,034 dan signifikan sebesar 0,905. Nilai signifikan tersebut lebih kecil dari $\alpha=0,05$ sehingga dapat diartikan bahwa variabel kompensasi berpengaruh positif dan signifikan terhadapKepuasan kerja. Dengan demikian, hipotesis kedua $\left(\mathrm{H}_{2}\right)$ dalam penelitian ini yang menyatakan bahwa kompensasi berpengaruh positif dan signifikan terhadap kepuasan kerja pegawai pada Badan Keuangan Daerah Provinsi Sumatera Barat, dinyatakan dapat diterima.

Menurut Davis dalam Tb.S Mangkuprawi (2004) Kepuasan Kerja adalah kepuasan pegawai terhadap perkerjaanya, antara apa yang diharapkan dengan apa yang diterima dari pekerjaan atau kantornya. Robbins (2003) menyatakan bahwa istilah kepuasan kerja merujuk kepada sikap umum seorang individu terhadap pekerjaan yang dilakukannya.

Penelitian oleh (Hestin Mutmainah, 2013). Pengaruh Kompensasi, Pelatihan, Dan Peran Supervisor Terhadap Kinerja Yang Dimediasi Oleh Kepuasan Kerja Pada Karyawan Paguyuban Batik Laweyan Surakarta. Hasil dari penelitian tersebut menunjukan bahwa kompensasi berpengaruh positif dan signifikan terhadap kepuasan kerja.

Hal ini bermakna bahwa jika semakin banyakkompensasi yang dimiliki oleh pegawaiPNS Badan Keuangan Daerah Provinsi, maka akan semakin baik kinerja pegawai pegawai Badan Keuangan Daerah Provinsi Sumatera Barat.

\section{Pengaruh Kepuasan Kerja Terhadap Kinerja Pegawai}

Berdasarkan hasil pengujian hipotesis ketiga, ditemukan bahwa variabel kepuasan kerjaberpengaruh positif dan signifikan terhadap kinerja pegawai Badan Keuangan Daerah Provinsi Sumatera Barat.Besaran koefisien regresi variabel kepuasan kerja adalah 1,609dan signifikan sebesar 0,119. Nilai signifikan tersebut lebih besar dari $\alpha=0,05$. Hal ini dapat diartikan bahwa variabel kepuasan kerjatidak berpengaruh positif dan signifikan terhadap Kinerja pegawai.Dengan demikian, hipotesis ketiga $\left(\mathrm{H}_{3}\right)$ dalam penelitian ini yang menyatakan bahwa kepuasan kerjatidak berpengaruh positif dan signifikan terhadap kinerja pegawai pada Badan Keuangan Daerah Provinsi Sumatera Barat, dinyatakan tidak diterima.

Kepuasan Kerja adalah sikap emosional yang menyenangkan dan mencintai pekerjaan.Sikap tersebut mencerminkan oleh moral kerja, kedisiplinan dan prestasi kerja.Kepuasan kerja dinikmati dalam perkerjaan ataupun diluar pekerjaan. Sehingga pegawai akan berusaha dan bahkan meningkatkan kinerjanya dalam peusahaan.

Penlitian oleh (Murti \& Srimulyani, 2013) dengan penelitian Pengaruh Motivasi Terhadap Kinerja Pegawai Dengan Variabel Pemediasi Kepuasaan Kerja Pada Pdam Kota Madiun. Hasil dari penelitian tersebut bahwa kepuasan kerja tidak berpengaruh positif dan signifikan terhadap kinerja.

Hal ini bermakna bahwa jika tidak baik kepuasan kerja yang dirasakan oleh pegawai pada Badan Keuangan Daerah Provinsi Sumatera Barat, maka akan 
semakin tidak baik pula Kinerja Pegawai yang diberikan oleh pegawai pada Badan Keuangan Daerah Provinsi Sumatera Barat.

\section{Pengaruh Kompensasi Terhadap Kinerja Pegawai YangDimediasi Oleh Kepuasan Kerja.}

Hasil pengujian hipotesis keempat, ditemukan bahwa variabel kepuasan kerjatidak memediasi antara kompensasi dan kinerja pegawai pada Badan Keuangan Daerah Provinsi Sumatera Barat. Terjadi apabila variabel bebas tidak berpengaruh signifikan terhadap variabel terikat setelah dikontrol oleh variabel mediasi. Hal ini dapat diketahui bahwa nilai signifikan Kompensasi terhadap Kinerja Pegawai setelah dimediasi oleh kepuasan kerja adalah 0,119 , nilai signifikan tersebut lebih besar dari $\alpha=0,05$ (0,119>0,05, tidak signifikan). Sementara itu diketahui bahwa besaran koefisien regresi variabel kepuasan kerja adalah 0,387 dan signifikan sebesar 0,000. Nilai signifikan tersebut lebih kecil dari $\alpha=0,05(0<0,05)$. Hal ini dapat diartikan bahwa variabel kepuasan kerja tidak memediasi secara signifikan pengaruh kompensasi terhadap kinerja pegawai pada PNS Badan Keuangan Daerah Provinsi Sumatera Barat.Dengan demikian, hipotesis keempat $\left(\mathrm{H}_{4}\right)$ dalam penelitian ini yang menyatakan bahwa kepuasan kerja tidak berfungsi sebagai intervening dalam mempengaruhi kompensasi terhadap kinerja pegawai Badan Keuanagan Daerah Provinsi Sumatera Barat, dinyatakan tidak diterima.

Penelitian oleh (Murti \& Srimulyani, 2013) dengan penelitian Pengaruh Motivasi Terhadap Kinerja Pegawai Dengan Variabel Pemediasi Kepuasaan Kerja Pada Pdam Kota Madiun.Hasil dari penelitian tersebut bahwa kepuasan kerja tidak memediasi secara siknifikan pengaruh kompensasi terhadap kinerja pegawai.

Hal ini bermakna bahwa jika tidak baik kepuasan kerja yang dirasakan oleh pegawai pada Badan Keuangan Daerah Provinsi Sumatera Barat, maka akan semakin tidak baik pula Kinerja Pegawai yang diberikan oleh pegawai pada Badan Keuangan Daerah Provinsi Sumatera Barat.

\section{SIMPULAN}

Dari hasil pengujian hipotesis yang telah dilakukan mengenai analisis Pengaruh Kompensasi terhadap Kinerja Pegawai dengan Kepuasan Kerja sebagai Intervening maka dapat ditarik kesimpulan sebagai berikut:1) Variabel Kompensasiberpengaruh positif dan signifikan terhadapKinerja Pegawai dengan nilai sig $0,905=0,95$, maka hipotesis diterima karna mendukung hipotesis $1\left(\mathrm{H}_{1}\right)$ bahwa kompensasi berpengaruh positif dan signifikan terhadap kinerja pegawai.2) Variabel kompensasi berpengaruh positif dan signifikan terhadap pengaruh kepuasan kerja dengan nilai sig 0,905>0,05, maka hipotesis diterima karna mendukung hipotesis $2\left(\mathrm{H}_{2}\right)$ bahwa kompensasi berpengaruh terhadap hubungan antara kepusan kerja.3)Variabel Kepuasan kerja berpengaruh memediasi dan signifikan terhadap pengaruh kompensasi dengan variabel kinerja pegawai dengan nilai sig $0,000<0,05$, maka hipotesis diterima karna mendukung hipotesis $3\left(\mathrm{H}_{3}\right)$ bahwa Kepuasan kerjaberpengaruh terhadap hubungan antara kompensasi dengankinerja pegawai.

\section{UCAPAN TERIMAKASIH}

Dengan selesainya dalam artikel penelitian Bapak Febryandhie Ananda, 
SE, M.Si selaku ketua STIE "KBP” Padang yang telah memberikan bimbingan dan fasilitas selama penulis menjadi mahasiswi.Ibu Lidya Martha, SE, MM selaku wakil ketua Sekolah Tinggi Ilmu Ekonomi "Keuangan, Perbankan dan Pembangunan" Padang.Ibu Maria Magdalena S.Pd,MM selaku pembimbing Akademik Manajemen tahun 2014.Ibu Febsri Susanti, SEI, MM selaku ketua program studi manajemen Sekolah Tinggi Ilmu Ekonomi "Keuangan, Perbankan dan Pembangunan" Padang.Ibu Aminar Sutra Dewi, SE, MSi selaku Pembimbing skripsi dan artikel yang memberikan izin kepada peneliti untuk pengambilan dan pengumpulan data dalam peneltian ini.

\section{DAFTAR REFERENSI}

Agus, P., Mahardika, C., Bagia, I. W., \& Yulianthini, N. N. (2016). Pengaruh kompensasi dan disiplin kerja terhadap kinerja karyawan pada hotel puri bagus lovina $1,4(1)$.

Ayu, D. G., \& Mayliza, R. (2019). Pengaruh Budaya Organisasi, Kompensasi Non Finansial, Dan Job Insecurity Terhadap Turnover Intention Pada PT. BPR Cincin Permata Andalas Cabang Padang. https://doi.org/10.31219/osf.io/nd8ta

Fathonah, S., \& Utami, I. (2011). Pengaruh Kompensasi, Pengembangan Karir, Lingkungan Kerja Dan Komitmen Organisasi Terhadap Kepuasan Kerja Pegawai Sekretariat Daerah Kabupaten Karanganyar Dengan Keyakinan Diri (Self Efficacy) Sebagai Variabel Pemoderasi. Igarss 2014, 1(1), 1-20. https://doi.org/10.1007/s13398-014-0173-7.2

Fendi, Z., \& Susanti, F. (2018). Pengaruh Kepuasan Kerja Terhadap Turnover Intention Dengan Komitmen Organisasi Sebagai Variabel Intervening Pada CV. Belibis Pariaman. https://doi.org/10.31227/osf.io/wumgx

Ghozali. (2001). analisis multivariate dengan program. semarang.

Hestin Mutmainah. (2013). Pengaruh kompensasi, pelatihan, dan peran supervisor terhadap kinerja yang dimediasi oleh kepuasan kerja pada karyawan paguyuban batik laweyan surakarta, 29, 1-20.

Hidayat, M., \& Dewi, A. S. (2018). Pengaruh Budaya Organisasi Dan Locus Of Control Terhadap Kinerja Pegawai Cabang PT. Pegadaian (Persero) Tarandam Padang. https://doi.org/10.31219/osf.io/9m2zr

Indahningrum, R. P., \& Handayani, R. (2009). Pengaruh Kepemilikan Manajerial,Kepemilikan Institusional, Dividen, Pertumbuhan Perusahaan,Free Cash Flow dan Profitabilitas terhadap Kebijakan Hutang Perusahaan. Jurnal Bisnis Dan Akuntansi, 11(3), 189-207.

Indrawati, A. D. (2013). Pengaruh Kepuasan Kerja Terhadap Kinerja Karyawan Dan Kepuasan Pelanggan Pada Rumah Sakit Swasta Di Kota Denpasar. Jurnal Manajemen, Strategi Bisnis Dan Kewirausahaan, 7(2), 135-140. 
Retrieved from http://ojs.unud.ac.id/index.php/jmbk/article/view/6997

Ketut, N., \& Juli, A. (n.d.). Pengaruh Kompensasi dan Motivasi Terhadap Kepuasan dan Kinerja Karyawan pada Hotel Bakung's Beach Cottages Kuta-Bali, 1585-1594.

Mayliza, R. (2019). Pengaruh Kompensasi Finansial, Lingkungan Kerja Dan Motivasi Kerja Terhadap Kinerja Pegawai Pada Kantor PDAM Kota Payakumbuh. https://doi.org/10.17605/OSF.IO/DZXAF

Mayliza, R. (2019). Pengaruh Kepuasan Kerja Dan Loyalitas Kerja Terhadap Organizational Citizenship Behavior (OCB) Pada Pegawai BPKPAD Di Madina. https://doi.org/10.17605/OSF.IO/5PVWB

Mekel, N. I. S. P. A. (2015). Pengaruh lingkungan kerja, kepuasan kerja dan kompensasi terhadap kinerja karyawan pada pt. Bank sulut cabang airmadidi, 3(1), 52-62.

Murti, H., \& Srimulyani, V. A. (2013). Pengaruh Motivasi Terhadap Kinerja Pegawai Dengan Variabel Pemediasi Kepuasaan Kerja Pada Pdam Kota Madiun. JRMA Jurnal Riset Manajemen Dan Akuntansi, 1(1), 10-17.

Murty, W. A., \& Hudiwinarsih, G. (2012). Pengaruh kompensasi, motivasi dan komitmen organisasional terhadap kinerja karyawan bagian akuntansi (studi kasus pada perusahaan manufaktur di surabaya. The Indonesian Accounting Review, 2(2), 215-228.

Nurcahyani, N. M. (2016). Pengaruh Kompensasi Dan Motivasi Terhadap Kinerja Karyawan Dengan Kepuasan Kerja Sebagai Variabel Intervening. E-Jurnal Manajemen, 5(1), 500-532.

Pottale, B. (2016). Pengaruh Proses Rekrutmen dan Seleksi Terhadap Kinerja Karyawan Pada PT. Bank SulutGo The Influence Of The Recruitmen Process For And Selection Of The Performance Of Employess At PT. Bank SulutGo. Berkala Ilmiah Efisien, 16(4), 453-464.

Rini, Dibyantoro, M. I. ardianto. (2003). No Title. Pengaruh kompensasi terhadap kinerja karyawan melalui motivasi kerja sebagai variabel intervening (studi pada karyawan pt duta oktan Semesta Palembang.

Sugiyono. (2015). statistik nonparametris. bandung. 